\title{
新しいしらす斜面の安定解析手法
}

\section{A New Slope Stability Analysis for Shirasu Slope}

\author{
酒匂一成*山田満秀 ${ }^{* *} \cdot$ 北村良介*** \\ Kazunari SAKO, Mituhide YAMADA and Ryosuke KITAMURA
}

\begin{abstract}
*学生会員 鹿児島大学大学院 理工学研究科 海洋土木工学専攻 (T890-0065 鹿児島県鹿児島市郡元 1-21-40) **正会員 工修 （株）ダイヤコンサルタント 仙台支店 （厂980-0011 仙台市青葉区上杉 3-4-48） ***正会員 工博 鹿児島大学教授 工学部 海洋土木工学科 (广890-0065 鹿児島県鹿児島市郡元 1-21-40)
\end{abstract}

\begin{abstract}
The inter-particle force due to meniscus at a contact point of soil particles is derived and then the relationship between suction and apparent cohesion is numerically obtained based on some probabilistic consideration on the soil particle size. A new slope stability analysis is proposed to analyze the stability of Shirasu slopes, in which Janbu method is applied to the slope failure caused by heavy rainfall. In the proposed stability analysis the change in apparent cohesion with the change in water content due to rainfall can be taken into account. The current safety factor can be calculated by a personal computer when the data on total amount and intensity of rainfalls are obtained in the real time.
\end{abstract}

Key Words : Shirasu, slope stability analysis, apparent cohesion, safety factor

\section{1. はじめに}

南九州地方の地盤は、様々な火山堆積物で覆われて いる。その中でもしらすは火确流堆積物の非溶結部と 定義されている有名な火山堆積物である。台風や梅雨 の時に豪雨が生じると、しらすからなる斜面の崩壊が 多発する。しらす斜面の崩壊のほとんどは、すべり厚 さが数十 $\mathrm{cm}$ 程度の表層すべり型崩壊である。この型 の崩壊の主な原因として、土中の含水比が増加するこ とにより、サクションが低下し、粒子間に㗢く粒子間 力が低下することによる見掛けの粘着成分の減少が挙 げられる。しかし、含水比の変化に伴う見掛けの粘着 成分の変化を定量的に評価する方法は、未だ確立され ていない。よって、従来の斜面安定解析は、降雨時の しらす斜面の安定性の定量的評価には適用できない。 豪雨時のしらす斜面の崩壊を予知するために有用な斜 面安定解析手法を開発する必要がある 1)。

本研究では、雨水の浸透による見掛けの粘着成分の 減少に着目し、新しい斜面安定解析手法を提案してい る。すなわち、粒子の接触点でのメニスカスによる粒 子間力を計算し、いくらかの確率論的手法を加えるこ とでサクションと見掛けの粘着成分との関係を定量的 に得る。そして、Janbu 法を適用してしらす斜面の表 層すべり型崩壊に対する安全率を求め、若干の考察を 行っている。

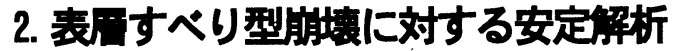

豪雨時にしらす斜面で生じる崩壊のほとんどが表層 すべり型崩壊である。表層すべり型崩壊が生じる要因 として挙げられるのが雨水の浸透による見掛けの粘着 成分の低下である。雨水が浸透すると土中の含水比が 増加し、サクションが低下する。サクションが低下す るとせん断強度パラメータである見掛けの粘着成分が 低下し、崩壊が生じる。そこで本研究では、しらす斜 面における表層すべり型崩壊について見掛けの粘着成 分に着目した。

表層すべり型崩壊は、傾斜角が $45 \sim 60$ 度の斜面で 多く発生する。すべり面の深さは数十 $\mathrm{cm}$ から $1 \mathrm{~m}$ 程度

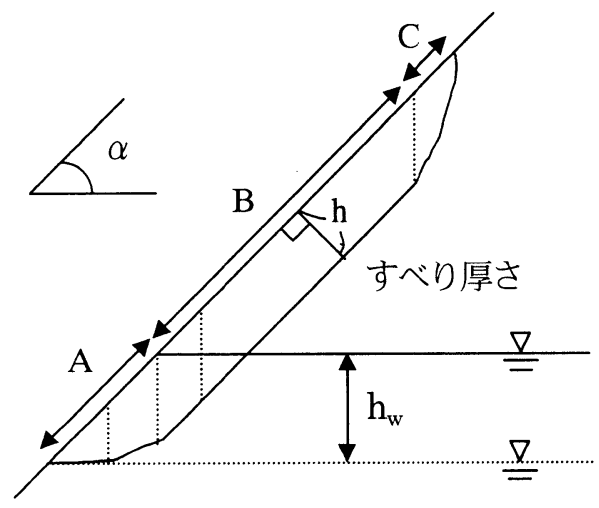

図-1．表層すべり型崩壊 
である。すべり面の形態は、図－1 に示すように上下 端で非円弧の形をなし、その間は直線的な形をしてい る。これまでの表層すべり型崩壊に対する解析は、斜 面を直線の半無限斜面とし、斜面全体の滑動に対する 力の釣り合いを考えた。しかし、実際の斜面の形は図 -1 のようであり、斜面の全体で崩壊する場合もある が、斜面内で局部的に崩壊する場合も多々ある。この ことを考慮すると、表層すべり型崩壊の解析を行うに は、斜面内の有限区間（特に法先、法尻）で起きる崩 壞について考える必要がある。ここでは、斜面安定解 析手法として Janbu 法を用いた。Janbu 法では安全率 が次のように求められる2!。

$$
F_{J}=\frac{\sum\left\lfloor\{c \cdot b+(W-\Delta V-U \cdot \cos \alpha) \cdot \tan \phi\} / m_{j}\right\rfloor}{\sum\{\Delta E+(W-\Delta V) \cdot \tan \alpha\}}
$$$$
m_{j}=\cos ^{2} \alpha+\sin \alpha \cdot \cos \alpha \cdot \tan \phi / F_{J}
$$

$$
\text { ここに、 } \mathrm{F}_{\mathrm{J}} \text { : 安全率 } \quad, \mathrm{b} \text { : スライス幅 }
$$

W : スライス自重 ， $\alpha$ : 斜面の傾斜角,

$\mathrm{V}:$ 鈶直方向のスライス間力,

$\Delta \mathrm{E}:$ スライス側面に働く間隙水圧のスライ ス間力,

$\Delta \mathrm{U}$ : スライス底面に働く間隙水圧のスライ ス間力.

式(1) 中の見掛けの粘着成分 $c$ に、第 3 節で導く式 (17) を適用することで降雨時の安全率の変化を知るこ とができる。

\section{3. 粒子間力から見掛けの粘单成分の算定}

\section{1 モデル化}

先に述べたように、斜面崩壊を起こす誘因の一つに 雨水の浸透による見掛けの粘着成分 c の低下が挙げら

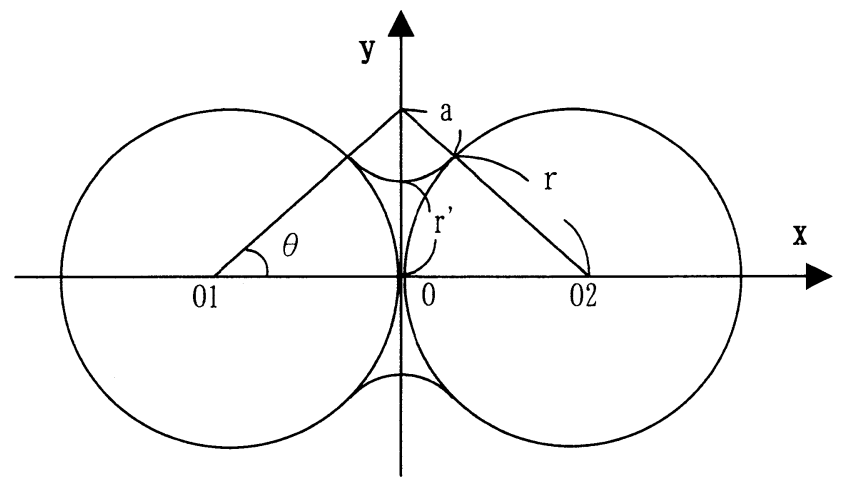

図-2. 2 粒子モデル
れる。見掛けの粘着成分 $\mathrm{c}$ に粒子間力 $\mathrm{F}_{\mathrm{i}}$ が大きく関係 していることは明らかであるので、ここでは粒子間力 $\mathrm{F}_{\mathrm{i}}$ に基因する見掛けの粘着成分 $\mathrm{c}$ を算定し、サクショ ン、含水比との関係について考察した。

図一2 に示すように粒子接点で間隙水によるメニス カスが形成され、粒子間力が生じる。表面張力やサク ションの効果を考慮し、粒子間力は次式で表される。

$F_{i}=2 \cdot \pi \cdot r^{\prime} \cdot T_{s}+\pi \cdot r^{\prime 2} \cdot s_{u}$

ここに、 $\mathrm{F}_{\mathrm{i}}$ : 粒子間力, $\mathrm{T}_{\mathrm{S}}$ : 表面張力,

$$
\begin{aligned}
& \mathrm{s}_{\mathrm{u}}: \text { サクション }\left(=\mathrm{u}_{\mathrm{a}}-\mathrm{u}_{\mathrm{w}}\right), \\
& \mathrm{r}, \text { : メニスカスの曲率半径. }
\end{aligned}
$$

式(2)において、右辺の第 2 項はサクションを含んで おり、粒子間力を求めるためには、含水比を得る必要 がある。北村ら ${ }^{31}$ は、不飽和土の間隙水の浸透挙動に 対して、数值力学モデルを提案した。図-3 (a) は、2、 3 個の土粒子からなる土塊の一要素を示したものであ る。これを図-3 (b) のように間隙部分を管径 D、傾き $\theta$ の円管に、土粒子実質部分を円管以外の不透水の固 体とに分けてモデル化した。このようにモデル化され たものを間隙モデルと称している。間隙モデルにより、 巨視的に見ると複雑な形状をしている間隙を微視的な 立場から物理的に意味のある量を用いてモデル化し、 いくらかの力学的、確率論的手法を用いることによっ て、間隙比 $\mathrm{e} 、$ 体積含水率 $\mathrm{W}_{\mathrm{v}}$ やサクション $\mathrm{s}_{\mathrm{u}}$ が次のよ うに得られる。

$$
\begin{aligned}
e & =\int_{0}^{x} \int_{-\frac{\pi}{2}}^{\frac{\pi}{2}} \frac{V_{P}}{V_{e}-V_{P}} \cdot P d(D) \cdot P c(\theta) d \theta d D \\
W_{V} & =\frac{e(d)}{1+e} \\
& =\frac{1}{1+e} \int_{0}^{d} \int_{-\frac{\pi}{2}}^{\frac{\pi}{2}} \frac{V_{P}}{V_{e}-V_{P}} \cdot P d(D) \cdot P c(\theta) d \theta d D
\end{aligned}
$$

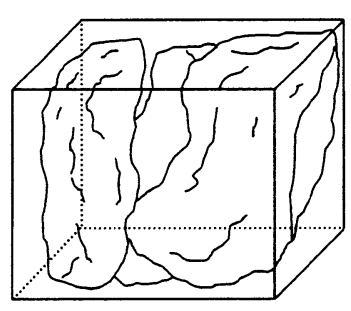

図-3(a).土塊の微小要素

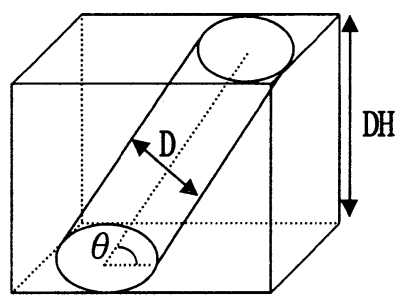

図-3 (b). モデル化された 一要素 
$s_{u}=\gamma_{w} \cdot h_{c}=\frac{4 \cdot T_{s} \cdot \cos \beta}{d}$

ここに、 e : 間隙比 ， $V_{p}$ : 円管の体積

$\mathrm{V}_{\mathrm{e}}:$ 素体積全体の高さ,

Pd (D) : 管径D の確率密度関数,

$\operatorname{Pc}(\theta)$ : 円管の傾き $\theta$ の確率密度関数,

$\mathrm{W}_{\mathrm{v}}$ : 体積含水率 ， $\mathrm{S}_{\mathrm{u}}$ : サクション,

$h_{\mathrm{c}}$ : 水頭 $\quad \mathrm{T}_{\mathrm{s}}$ : 表面張力,

$\beta:$ 毛細管と水の接触角,

$\gamma_{\psi}:$ 水の単位体積重量,

$\mathrm{d}$ : 間隙水を保持する円管の最大管径.

式(5) を式 (2) に代入すると 1 接点当たりの粒子間力 を得ることができる。

式 (2) で得られた粒子間力 $F_{i}$ は 1 接点当たりの力で あるので、見掛けの粘着成分と関連づけるためには単 位面積当たりの粒子接点数を得る必要がある。

図-4 は土粒子の形状が球であると仮定し、その球粒 子が単位長さの立方体に堆積した様子を示したもので ある。この状態における単位体積当たりの粒子数 $\mathrm{NV}$ と間隙比 e との関係は次式のようになる。

$$
N v=\frac{1}{1+e} \cdot\left(\frac{3}{4 \cdot \pi \cdot r^{3}}\right)
$$

ここに、Nv：単位体積当たりの粒子数，

$\mathrm{e}:$ 間隙比

$r:$ 土粒子半径.
本研究では、図ー5 に示すようにせん断すべり面は 曲面であると考えた。その曲面が半球面の集合である と仮定すると、仮想せん断すべり面上の単位面積当た りの粒子数 $\mathrm{Np}$ は、次式のようになる。

$N p=N v \cdot 2 \cdot r=\frac{1}{1+e} \cdot \frac{3}{2 \cdot \pi \cdot r^{2}}$

\section{ここに、 $\mathrm{Np}$ : 単位面積当たりの粒子数}

単位面積当たりの粒子接点数を求めるために、 1 粒 子当たりの粒子接点数について考える必要がある。1 粒子当たりの粒子接点数を求めるために、 1 粒子当た りの粒子接点数と間隙比との関係を経験的に導き出し た Field の経験式 "を用いた。その式を次式に示し、 図-6 に間隙比と 1 粒子当たりの粒子接点数の関係を示 す。

$C a=\frac{12}{1+e}$

ここに、 Ca : 1 粒子当たりの接点数

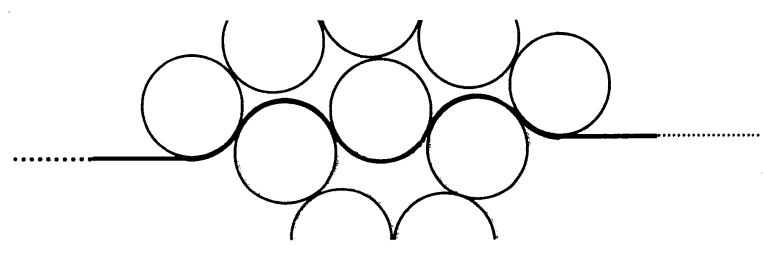

図－5．仮想せん断面

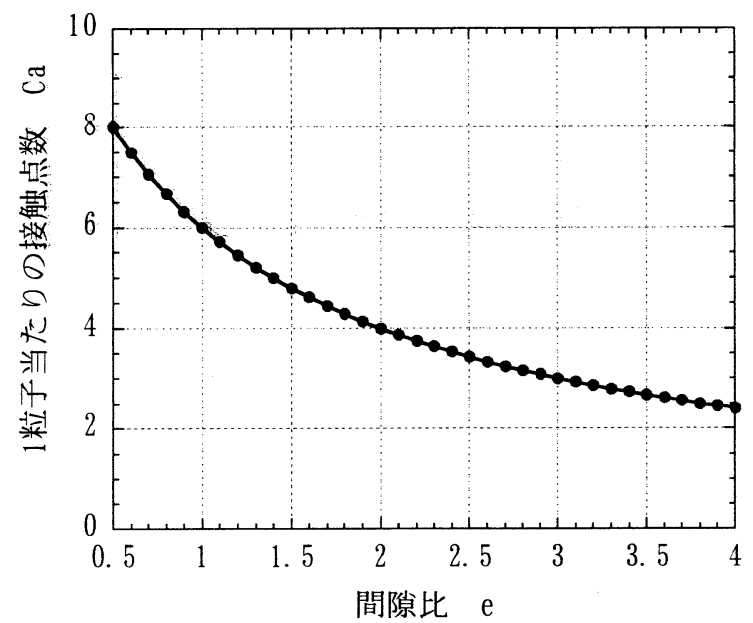

図一6. 間隙比と 1 粒子当たりの粒子接点数 の関係 
式 (7)、（8) から仮想せん断面での単位面積当たりの粒 子接点数が次式のように得られる。

$N c=\frac{C a}{2} \cdot N p$

ここに、 $\mathrm{Nc}$ : 単位面積当たりの粒子接点数

図ー7 は、仮想せん断面上の 1 つの粒子を取り出し、 その半球を示したものである。図ー7 で色付けされた帯 状部分に存在する粒子接点数 $\mathrm{dN}$ は次式のようになる。

$d N=N c \cdot D(\eta) \cdot d s$

ここに、 $\eta$ : 接触角, $\mathrm{ds}:$ 帯状部分の面積

$\mathrm{D}(\eta)$ : 接点角 $\eta$ 時の帯状部分における接触 点の確率密度関数.

式(10) 中の $\mathrm{D}(\eta)$ の具体的な関数として、接触点数が 接触角 $n=\pi / 2$ の時に最大で、 $\eta=0$ の時に最小である とし、その変化が線形であると仮定することで、接触点 の確率密度関数 $\mathrm{D}(\eta)$ が次式のように表される。

$D(\eta)=\frac{\eta}{\pi / 2-1}$

図-7において、接触点において水平方向と鉛直方向 の力の釣り合いを考えると、次式が導かれる。

$$
\begin{aligned}
& \overrightarrow{H^{\prime}}=\vec{H}+\sum\left(\overrightarrow{F_{i}} \cdot \cos \eta\right) \\
& \overrightarrow{V^{\prime}}=\vec{V}+\sum\left(\overrightarrow{F_{i}} \cdot \sin \eta\right)
\end{aligned}
$$

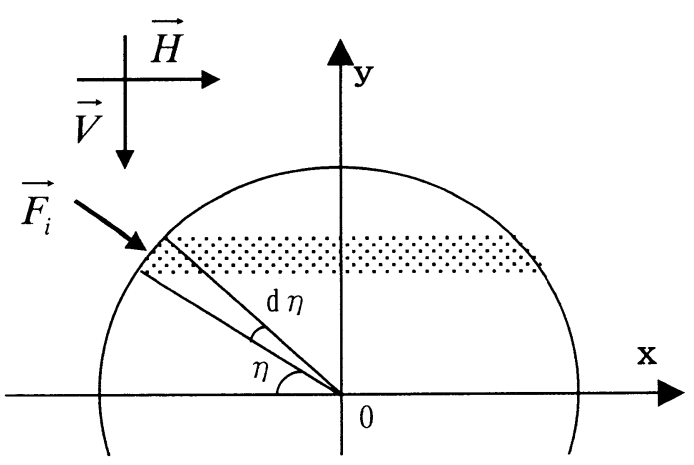

図一7. 仮想せん断面上の 1 粒子における力の 釣り合い
ここに、 $\overrightarrow{H^{\prime}}$ : 接点角 $\eta$ の時の帯状部分に作用する水 平方向の合力,

$\overrightarrow{V^{\prime}}:$ 接点角 $\eta$ の時の帯状部分に作用する鉛 直方向の合力,

$\vec{H}$ : ある1粒子すべての接点に作用してい る力の平均的な合力の水平成分,

$\vec{V}$ : ある 1 粒子すべての接点に作用してい る力の平均的な合力の鈶直成分,

$\overrightarrow{F_{i}}$ : 粒子接触面に垂直に働く粒子間力.

式(12)、(13)の比をとると、次式が得られる。

$\frac{\overrightarrow{H^{\prime}}}{\overrightarrow{V^{\prime}}}=\frac{\vec{H}+\sum\left(\overrightarrow{F_{i}} \cdot \cos \eta\right)}{\vec{V}+\sum\left(\overrightarrow{F_{i}} \cdot \sin \eta\right)}=\tan \delta$

\section{ここに、 $\delta:$ 粒子間の平均的摩擦角}

式(14)で表される力の釣り合いを単位面積当たりの力 の釣り合いに置き換えると、次式が得られる。

$$
\begin{aligned}
\tau= & \sum\left(\overrightarrow{F_{i}} \cdot \sin \eta\right) / S \cdot \tan \delta-\sum\left(\overrightarrow{F_{i}} \cdot \cos \eta\right) / S \\
& +\sigma \cdot \tan \delta
\end{aligned}
$$

ここに、 $\tau:$ せん断応力,

$\sigma:$ 垂直応力,

S : せん断すべり面の面積.

式(15)をモール・クーロンの破壊基準式と対応させる と、次のようになる。

$\phi=\delta$

$c=\sum\left(\overrightarrow{F_{i}} \cdot \sin \eta\right) / S \cdot \tan \phi$

$$
-\sum\left(\overrightarrow{F_{i}} \cdot \cos \eta\right) / S
$$

ここで、 $\phi$ : 内部摩擦角，

$\mathrm{c}$ : 見掛けの粘着成分.

式 (2)、（10)、（11）、（17）を用いることによって、見 掛けの粘着成分が次式のように得られる。 


$$
\begin{aligned}
c & =\left\{\tan \phi \cdot \int_{0}^{\pi}\left(\overrightarrow{F_{i}} \cdot \sin \eta\right) d N-\int_{0}^{\pi}\left(\overrightarrow{F_{i}} \cdot \cos \eta\right) d N\right\} / S \\
& =\frac{\pi}{\pi-2} \cdot \overrightarrow{F_{i}} \cdot N c \cdot \tan \phi
\end{aligned}
$$

\section{2 数値計算}

しらすに対応する土質材料を想定し数值計算を行った。 想定した材料の土質パラメータを表一1 に示す。計算の 結果として、間隙水を保持する円管の最大管径 d を介し て水分保持特性が式 (4)，(5)、サクション-見掛けの粘着 成分の関係が式 (5)，(18) から得られる。

数值計算によって得られた水分保持特性を図一8に示 す。図-8 から雨水が浸透することにより、土中の含水 比が増えサクションが低下していくことがわかる。飽和 する含水比 $25 \%$ 付近では、サクションがゼロになろうと する傾向が見られる。

表-1. 入力パラメータ

\begin{tabular}{|c|c|}
\hline 土粒子の密度 $\left(\mathrm{g} / \mathrm{cm}^{3}\right)$ & 2.37 \\
\hline 水の表面張力 $(\mathrm{N} / \mathrm{m})$ & $7.355 \mathrm{E}-02$ \\
\hline 土粒子の半径 $(\mathrm{cm})$ & 0.012 \\
\hline 内部摩擦角 ()$\left.^{\prime}\right)$ & 35.0 \\
\hline 素体積高さ $(\mathrm{cm})$ & 0.002 \\
\hline 管径の平均 $(\mathrm{cm})$ & 0.0012 \\
\hline 管径の標淮偏差 $(\mathrm{cm})$ & 0.0008 \\
\hline $\begin{array}{c}\text { 管の傾き } \theta \text { の } \\
\text { p. d. f } \text { の最低高さ }\end{array}$ & 0.159 \\
\hline
\end{tabular}

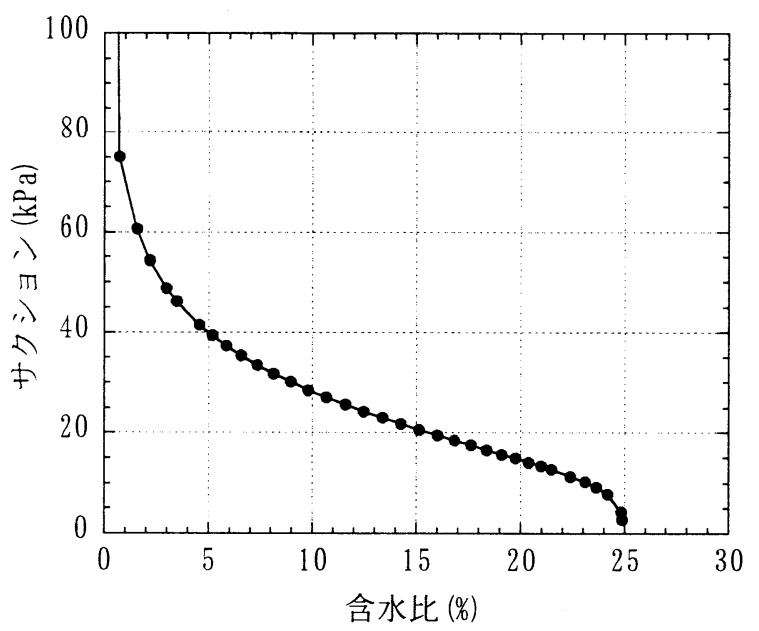

図-8. 水分保持特性
図ー9 は、サクションとサクションの効果による見掛け の粘着成分の減少量を表している。この図では、計算で 得られた含水比約 $0.0 \%$ 時のサクション $340 \mathrm{kPa}$ を基準 として、サクションの変化に対する見掛けの粘着成分の 変化を表している。雨水が浸透することによりサクショ ンが減少していくことで見掛けの粘着成分が減少してい くことが図より見て取れる。特に、サクションが約 $80 \mathrm{kPa}$ の付近から、サクションの低下に対して見掛けの粘着成 分が急激に減少していることがわかる。

せん断試験で得られる見掛けの粘着成分は、サクショ ンの効果によるものの他に土粒子同士のかみ合わせ、セ メンテーションによるものを含んでいる。そこで、せん 断試験で得られた見掛けの粘着成分がサクションの変化 によってどのように変化するかについて考える。例えば、 含水比が約 $0.0 \%$ 、サクションが $340 \mathrm{kPa}$ という土質材 料をせん断し、得られた見掛けの粘着成分が約 $8.0 \mathrm{kPa}$ であったと想定すると、図一10 が得られる。図-10 か ら、雨水が浸透し、サクションが低下することで見掛け の粘着成分が咸少していく様子がわかる。

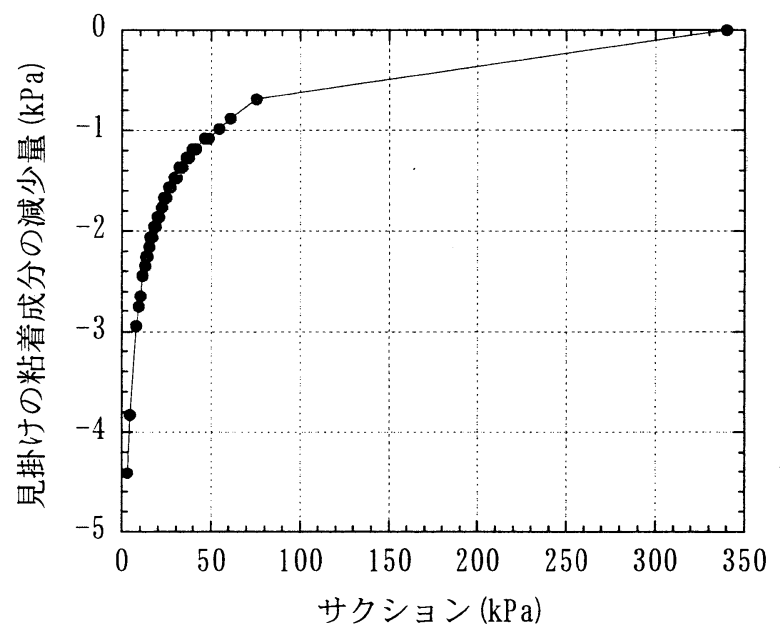

図-9. サクションと見掛けの粘着成分 の減少量の関係

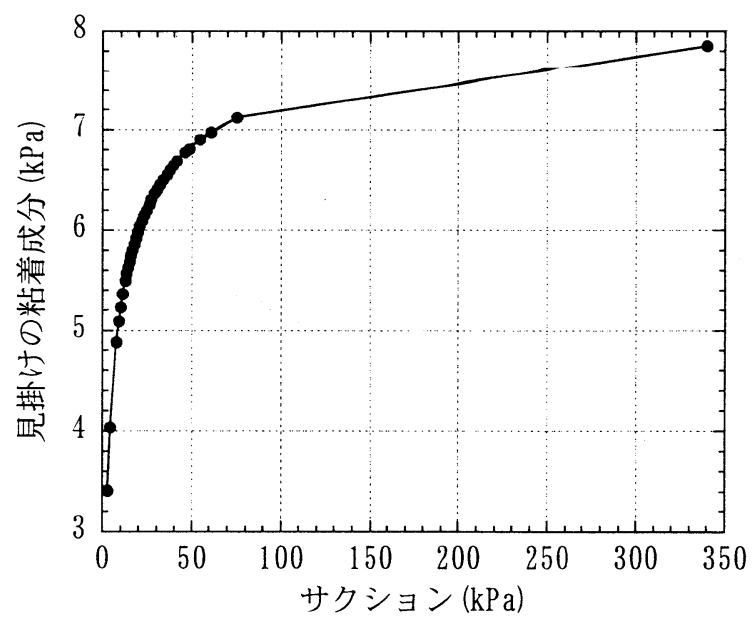

図一10. サクションと見掛けの粘着成分 の関係 
これらの結果は、しらす斜面での表層すべり型崩壊の 誘因である雨水の浸透による見掛けの粘着成分の減少 を定量的に表すことができることを示している。

\section{4. 結果と考察}

しらす斜面を想定する。土質パラメータは表一1の 值を用い、しらす斜面は表一2 に示す形状等を想定す る。計算結果を図ー11 に示す。図ー11 は見掛けの粘 着成分と安全率との関係を示している。この図から、 雨水が浸透し見掛けの粘着成分が低下することにより 安全率が減少していく様子がわかる。すべり面の深さ が $30 \mathrm{~cm}$ と $50 \mathrm{~cm}$ の時の安全率を比較すると、 $50 \mathrm{~cm}$ の方 が安全率が小さいことが見て取れる。また、すべり厚 さが浅い方ほど見掛けの粘着成分の変化量に対する安 全率の変化の割合が大きくなっていることがわかる。 このことから比較的浅い所で生じる表層すべり型崩壊 において見掛けの粘着成分が重要なパラメータになっ ていることがわかる。

表一2. 入力パラメータ

\begin{tabular}{|c|c|}
\hline 斜面の傾斜角 ( $)$ & 50.0 \\
\hline すべり長さ $(\mathrm{m})$ & 20.0 \\
\hline すべり土塊の分割数 & 5.0 \\
\hline スライス幅 $(\mathrm{m})$ & 1.0 \\
\hline $\mathrm{A}$, C部分の長さ $(\mathrm{m})$ & 4.0 \\
\hline B部分の長さ $(\mathrm{m})$ & 12.0 \\
\hline すべり厚さ $(\mathrm{cm})$ & $30.0,50.0$ \\
\hline 地下水 & 無し \\
\hline 内部摩擦角 ${ }^{\circ}$ ) & 35.0 \\
\hline
\end{tabular}

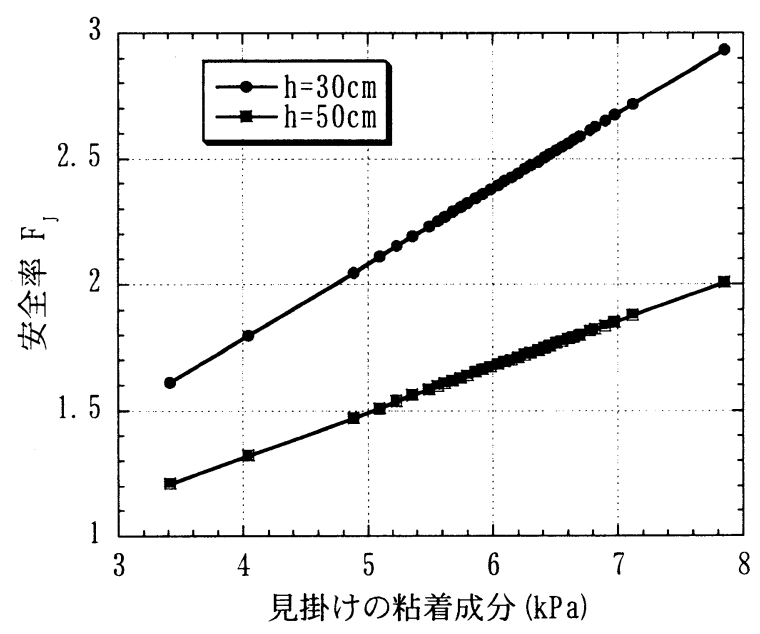

図-11. 見掛けの粘着成分一安全率の関係
次に表ー3 に示すようなしらす斜面を想定し、地下 水の有無が安全率に与える影響について検討する。図 -12 に計算結果を示す。図-12 では、地下水がすべり 土塊内に存在しない場合と存在する場合について検討 を行った。ここに、すべり土塊内に存在しない場合と は、図-1 ですべり面の最下端に地下水位があり、地下 水がすべり土塊内に存在する場合とは、地下水位線が すべり面の最下端から $2 \mathrm{~m}$ 上方にあるとした。この図 より地下水が存在している方が、すべり厚さに関係な く危険度が増していることがわかる。

すべり厚さ $50 \mathrm{~cm}$ 、斜面長さ $20 \mathrm{~m}$ 、地下水無しで、斜 面の傾斜角を $40^{\circ}, 50^{\circ}, 60^{\circ}$ と変化させた時の安全 率への影響を検討した結果が図一13である。この図か ら角度が大きくなれば安全率が小さくなることがわか る。

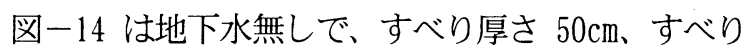
長さ $20 \mathrm{~m}$ 、傾斜角 $50^{\circ}$ での非円弧部分 (図-1の A C) の長さを 1 としてときの対する平面すべり部分 (図-1 のB) の長さの違いによる影響を考えた。図よりすべり 長さが同じである場合、平面すべり部分の長さの大き い方が危険であると言える。

$$
\text { 表一3. 入力パラメータ }
$$

\begin{tabular}{|c|c|}
\hline 斜面の傾斜角 ( () & 30.0 \\
\hline すべり長さ $(\mathrm{m})$ & 20.0 \\
\hline すべり土塊の分割数 & 5.0 \\
\hline スライス幅 $(\mathrm{m})$ & 1.0 \\
\hline $\mathrm{A}$ C C部分の長さ $(\mathrm{m})$ & 4.0 \\
\hline B部分の長さ $(\mathrm{m})$ & 12.0 \\
\hline 表層土厚 $(\mathrm{cm})$ & $50.0,100.0$ \\
\hline 内部摩擦角 $\left.{ }^{\circ}\right)$ & 35.0 \\
\hline
\end{tabular}

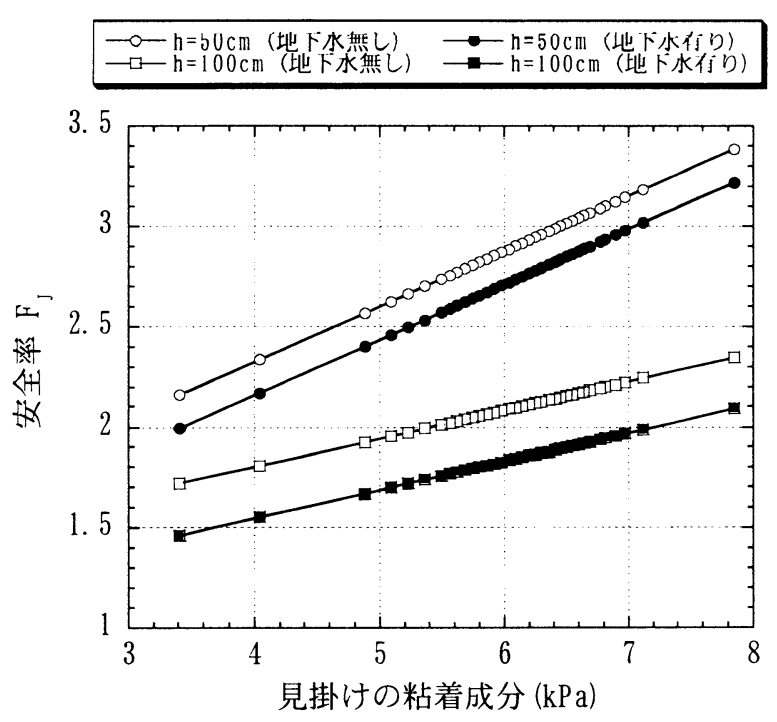

図-12. 見掛けの粘着成分-安全率の関係 


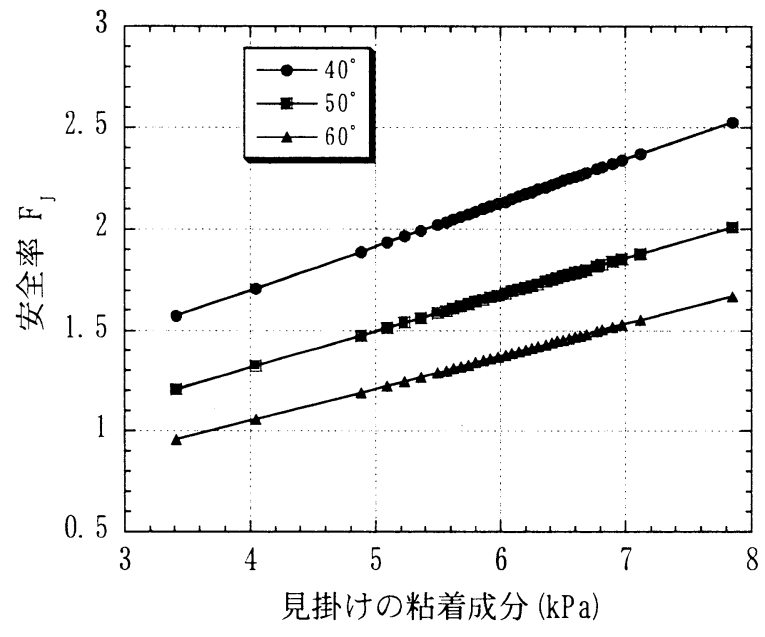

図-13．見掛けの粘着成分-安全率の関係

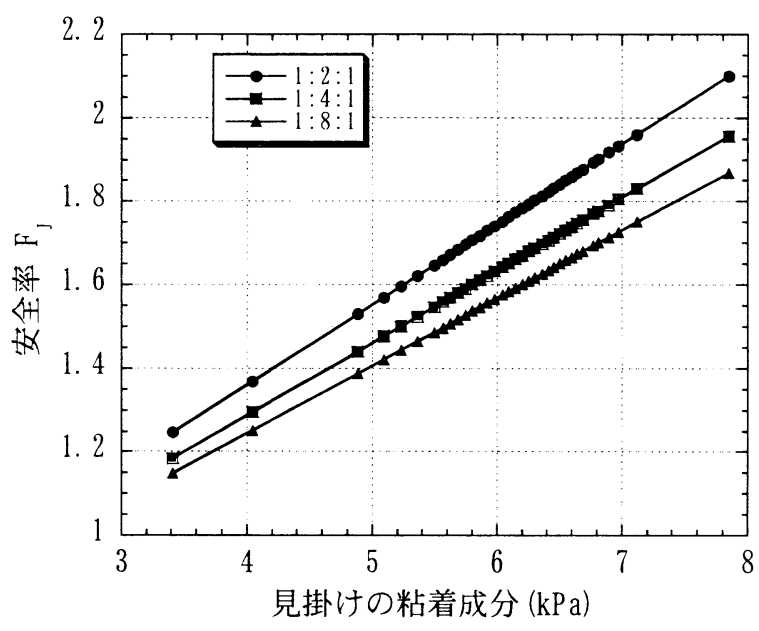

図-14. 見掛けの粘着成分-安全率の関係

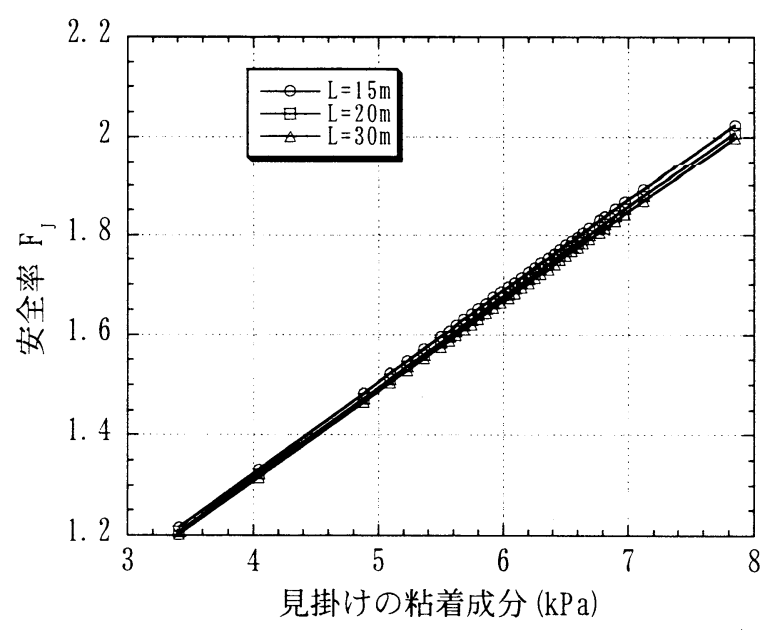

図-15. 見掛けの粘着成分-安全率の関係
図一15 は地下水無しで、すべり厚さ $50 \mathrm{~cm}$ 、傾斜角 $50^{\circ}$ 、非円弧部分 (図-1 の A C) と平面すべり部分 (図 -1 のB) の長さの比を $1: 3: 1$ に固定し、すべり長さを 15m、20m、30m とした場合である。図よりすべり長さ を変えても非円弧部分と平面すべり部分の比が同じで あれば、ほとんど安全率には影響がないと言える。こ のことからすべり長さよりも非円弧部分に対する平面 すべり部分の長さが重要であると言える。

しらす斜面に危険を及ぼす素因について検討した結果、 表層すべり型崩壞においては見掛けの粘着成分、地下 水の存在、斜面の傾斜角や非円弧部分の長さに対する 平面すべり部分の長さの比が斜面の危険度に大きな影 響を与えていると言える。

\section{5. まとめ}

本研究では、豪雨時のしらす斜面における表層すべ り型崩壊を予測するために有用な斜面安定解析手法を 提案し、若干の考察を行った。しらす斜面での表層す ベり型崩壊の誘因の 1 つである雨水の浸透による見掛 けの粘着成分の減少量をサクション、含水比と関連づ け、定量的に評価する手法を提案した。地下水の存在、 斜面の傾斜角や非円弧部分の長さに対する平面すべり 部分との長さの比の影響を調べるためのパラメトリッ クな計算を行い、定量的な考察を加えた。

今後は、モデル土槽での斜面崩壊試験、実斜面での 崩壊事例との比較による計算手法の妥当性の検証を行 っていきたい。

謝意 : 本研究は科研費基盤(B),(C)（代表 : 北村）の援 助を受けた。ここに謝意を表します。

\section{参考文献}

1) 山田満秀, 北村良介: 土木学会第 51 回年次学術講演 会概要集第 3 部 (A)、pp. 428〜429、1996.

2）地盤工学会編: 斜面安定解析入門、pp. 52〜 65、1996.

3) Ki tamura, R, Fukuhara, S, Uemura, K, Ki sanuki, G, and Seyama, M : A numerical model for seepage through unsaturated soil, Soils and Foundations, Vol. 38, No. 4, pp. 261-265, 1998.

4) Field, W, G. : Towards the Statistical Deformation of a Granular Mass, Proc. 4th A. and N. Z. Conf. SMFE, pp. 143-148, 1963.

(2000 年 4 月 21 日受付) 